\title{
Two Main Conditions for Collapse of the Bubble Economy of China-Large Number of Unsold Houses and Deregulation of Deposit Interest Rates
}

\author{
Goro Takahashi \\ International Center for Chinese Studies, Aichi University, Nagoya, Japan \\ Email: tagold@knh. Biglobe.ne.jp
}

Received 21 January 2015; accepted 23 March 2015; published 27 March 2015

Copyright @ 2015 by author and Scientific Research Publishing Inc.

This work is licensed under the Creative Commons Attribution International License (CC BY). http://creativecommons.org/licenses/by/4.0/

\section{(c) (i) Open Access}

\section{Abstract}

There are two kinds of asset bubble in China, and they are formed through these two assets, real estate assets and financial assets. Most studies looking into China's economy said that the Chinese bubble will collapse soon. Majority of these studies, however, provide unclear reasons. In addition, they emphasize mostly on the bubble as the reason of the predicted collapse. Data gathered through fieldwork concerning real estate developers, non-banking companies, normal banks, local governments, and various housing construction sites in three cities of China and through analyses of literature, this paper studied two kinds of asset bubbles which are developing in China. And this research done through the fieldwork is insisted on that the bubble economy of China will not collapse easily. But when some conditions occur, the bubble economy will collapse. One of the conditions of the collapse is the number of unsold houses keeps increasing further. Many developers are facing financing problems. If the number of bankrupt developers increases, the bubble will collapse. Another important condition is that the deregulation of the deposit interest rate by PCB. Therefore, the most important thing is the authorities involved must strengthen the management ability of developers. In addition, the policy measure used to mitigate the deposit interest rates policy and its impact.

\section{Keywords}

Bubble Economy, Farmland, Shadow Banking, Deposit Interest Rates, Unsold Houses

\section{Introduction}

This paper presents two statuses through which the possibility of collapse of the bubble economy of China can

How to cite this paper: Takahashi, G. (2015). Two Main Conditions for Collapse of the Bubble Economy of China-Large Number of Unsold Houses and Deregulation of Deposit Interest Rates. Journal of Financial Risk Management, 4, 40-55. 
be viewed and two kinds of asset bubbles which play the major roles in the collapse. Fieldwork was carried out in the cities of Beijing, Harbin and Xinxiang (Henan province); the time was June and August in 2014 (NHKTV reported on my field work as a special program).

Most studies looking into China's economy said that the Chinese bubble will collapse soon. Majority of these studies, however, provide unclear the reasons. This paper discusses two problems, one of them is the reasons of Chinese bubble has not collapsed, and the other is the reasons of the collapse, if it will happen.

Data gathered through fieldwork concerning real estate developers, non-banking companies, normal banks, local governments, and various housing construction sites in three cities of China and through analyses of literature, this paper studied two kinds of asset bubbles which are developing in China.

The Chinese bubble economy will suffer a latent collapse, but the latent collapse will be concealed by a powerful government. Nevertheless, if the management policy for such developers go wrong, and the financial authority fails to control the financial policies, especially deposit interest rate regulatory policy, the collapse of the Chinese bubble will obvious and will not be latent.

\section{The Relation between Real Estate Bubble and Financial Bubble in China}

Chinese economy is drowning in real estate bubble and financial bubble. Previous studies mentioned that the Chinese economy is in a serious bubble situation. "For many analysts, the Chinese economy is spurred by a bubble in the housing market, probably driven by the fiscal stimulus package and massive credit expansion, with possible adverse effects to the real economy" (Christian Dreger \& Yangun Zhang, 2010). Indeed, different housing bubble levels have existed in Beijing and Shanghai in the last 10 years. Beijing housing market had a relatively serious bubble level in 2001, 2007, 2009 and 2010. Shanghai housing market had a relatively serious level in 2009 and 2010 (Chai Ning \& Oh Dong Hoon, 2012). Other studies went on as far to say that the Chinese bubble will collapse soon (Jericho, 2014; Ranasinghe, 2014).

There are two kinds of asset bubbles in China which are formed through real estate assets and financial assets. These two kinds of bubbles interact with each other through an "Alchemy", which involves farmland. The basic reason which the Chinese bubble arise from is the fact that farmland in China is not priced as long as it is cultivated by farmers. We can therefore say that the Chinese bubble has a tricky part involving land.

Farmers do not have ownership of farmland, so a farmland may be expropriated by local governments with small compensation given to farmers. Then the land could be sold to someone and be used outside of agricultural purposes. The price of farmland is zero, but if one piece of the same land is sold for the purpose of non-agricultural usage, then the land immediately appreciates in value. In the case of selling a piece of land in a huge city, a piece of land is sold for several ten thousand Yuan or more per one square meter. On the other hand, a piece of farmland has no market price mechanism, but when the same land is converted to be used for nonagricultural purposes, that same land gets into the market price mechanism. Through this mechanism, huge money will flow into the local governments first, after that the money moves to financial shadow banking market and real estate market. The area of farmland expropriated for about 20 years from 1995 to 2012, which is the same as the area of conversion to non-agricultural usage, is shown in Figure 1. According to this figure, the area began abruptly increasing since 2001. At about the same time, the Chinese economy encountered a bubble situation. The expropriated average land area per year is about $1500 \mathrm{~km}^{2}$, and the amount has reached to 1,922,533 $\mathrm{km}^{2}$ after about 20 years.

The estimated value of the land area converted to non-farmland is shown in Figure 2. The black curb means the value of new converted land from farmland, red means the value of resale of the new converted land, and blue means the value of the land which was sold twice. During the bubble period, a piece of land is sold several times to get sales gains. When a sale is repeated, the sales profit is always ensured, and the price also goes up at the same ratio. The point in the blue curb indicating 20 trillion Yuan in 2012 means that the accumulated value of the converted farmland since 1995 after the land had been sold twice during the time when land price increase rate was zero. If the change in price increase rate is considered, the value is higher than 20 trillion Yuan. This is one structural aspect of the Chinese bubble economy.

By analyzing the abovementioned aspects, we can understand that the relation between real estate bubble and financial bubble in China is so strong. The important point to consider about the Chinese bubble is that farmland is the mother of the bubble economy in China.

China's bubble economy has started in the early 2000 as shown in Figure 3. This paper has adopted consumer 


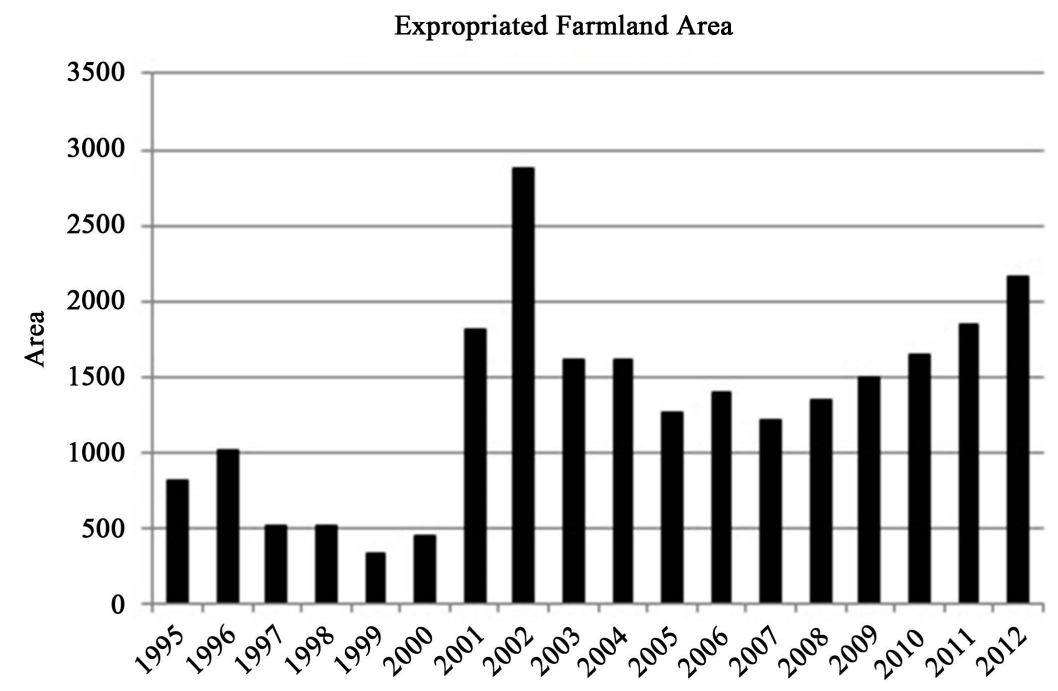

Figure 1. Expropriated farmland area $\left(\mathrm{km}^{2}\right)$. Source: NBSC.

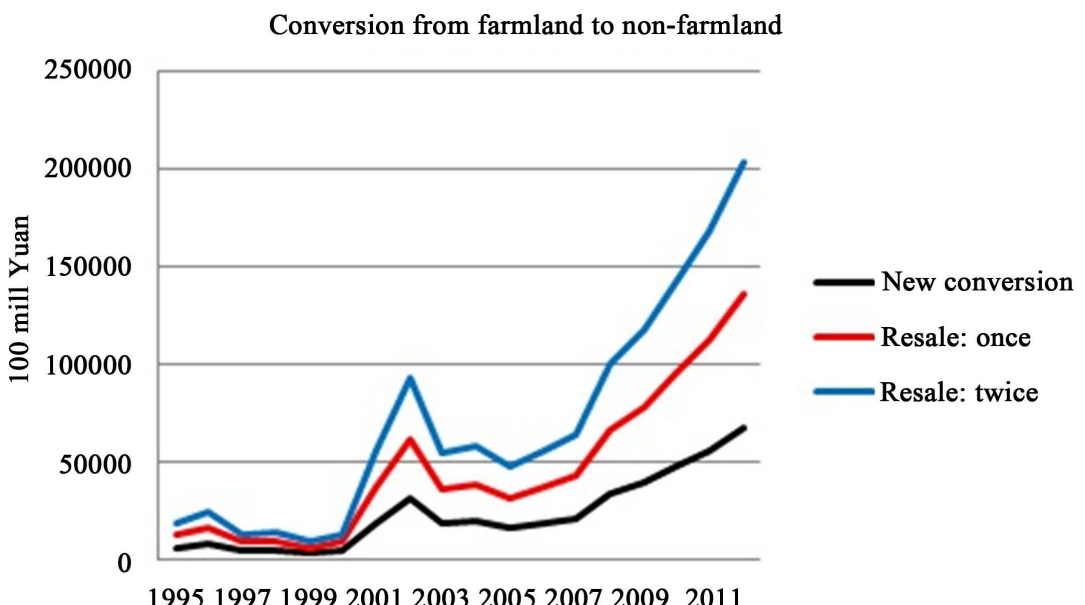

Figure 2. Conversion from farmland to non-farmland. Source: NBSC.

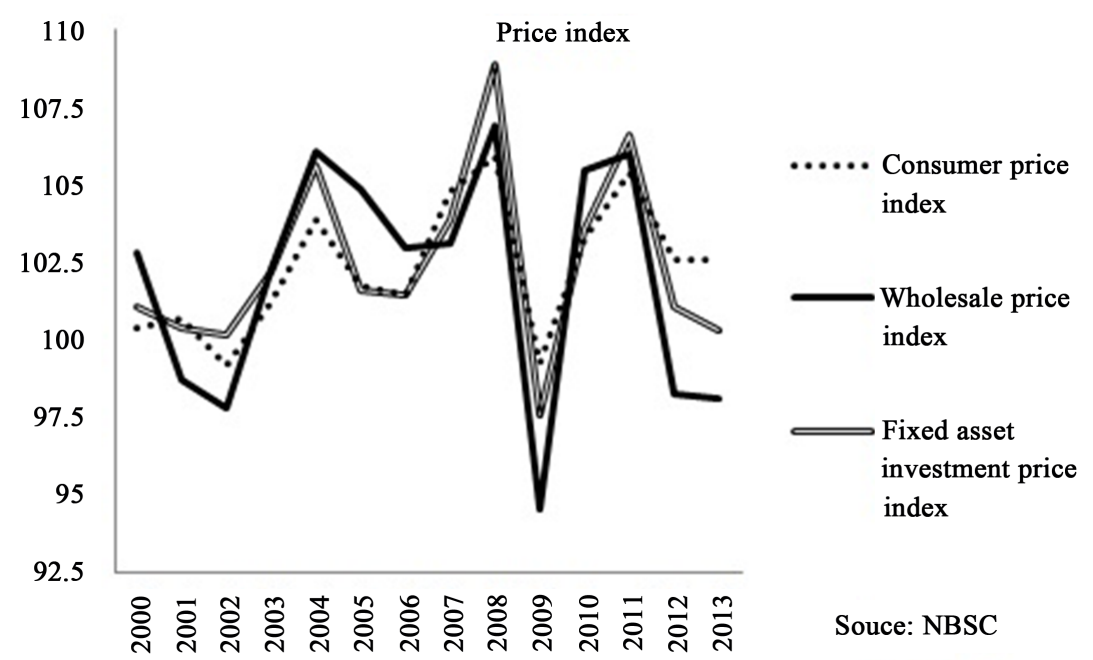

Figure 3. Price index (Previous year $=100)$. Source: NBSC. 
price index, wholesale price index, and fixed investment price index as the indicators of bubble economy. Fixed investment price index includes house price. This figure shows these indexes went up for 6 years from 2002 to 2008, particularly the price increase of $2.5 \%$ - 7.5\% per year by 2009 when the so called Riemann shock happened. The form of the rising curb of these indexes is almost the same, which means that it is one of the phenomena of the states of China's bubble economy. The trends of the indexes coincide to the trends of the estimated value of the land area which was converted to non-farmland shown in Figure 2.

Furthermore, this can be verified from a financial point of view as shown in Figure 4. Figure 4 shows the monthly curb of M2 from 2002 to 2014. The index is increasing by the month, and the fluctuation range is 0.998 to 1.045. The trend is divided for two periods or stages, from 2002 to 2008 and 2009 to 2014. The fluctuation range of the former is 1.005 to 1.030 , and the latter is 0.998 to 1.045 . The range of 2002 to 2008 is smaller than the period of 2009 to 2014. The latter period is more unstable than the former, which suggests that Riemann shock allowed the Chinese bubble economy to become more unstable with regard to the financial market. This means the Chinese economy needs much of M2 because the growth of GDP became moderate and the growth rate of GDP began to slow down to a level of $7 \%$ from $10 \%$ after the Riemann shock. Money is also overflowing in the real economy and financial market since the Chinese government supplied 4 trillion Yuan to support the private sector.

The fact of money multiplier, shown in Figure 5, which counts more than 20 times over, is one of the bigger characteristic of China. This index is around 10 times that of USA and EU countries and Japan (Takahashi, 2013). As seen above, M2 of China is increasing rapidly, and this speed is highest in the world economy. As a

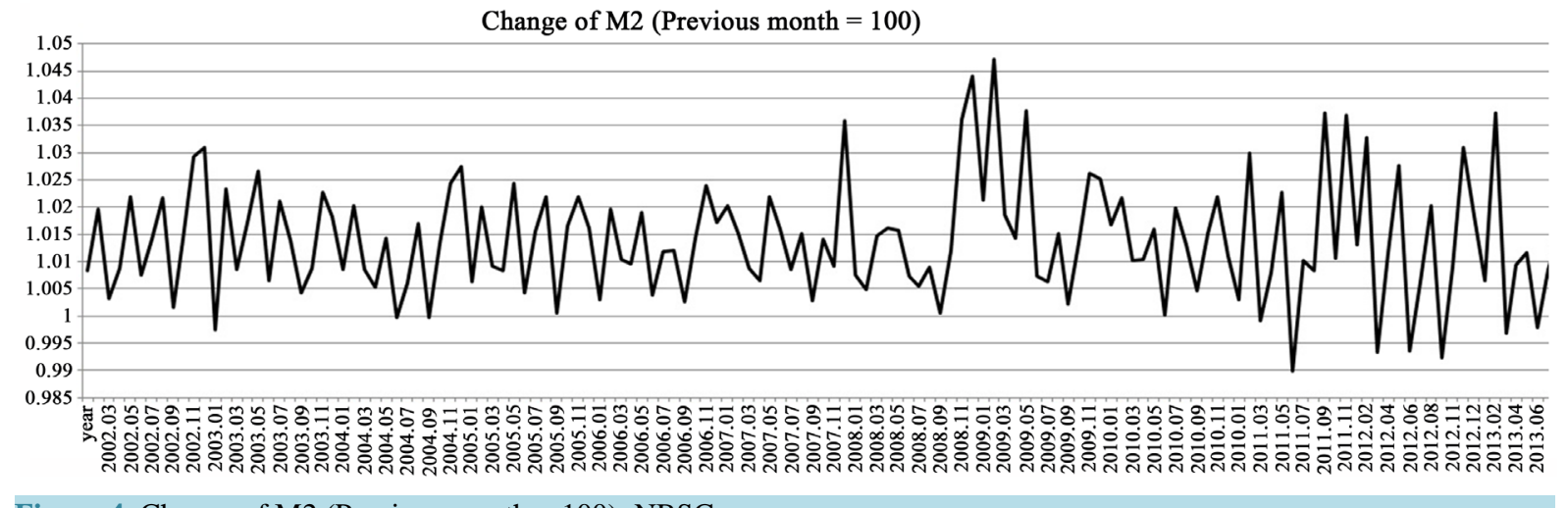

Figure 4. Change of M2 (Previous month =100): NBSC.

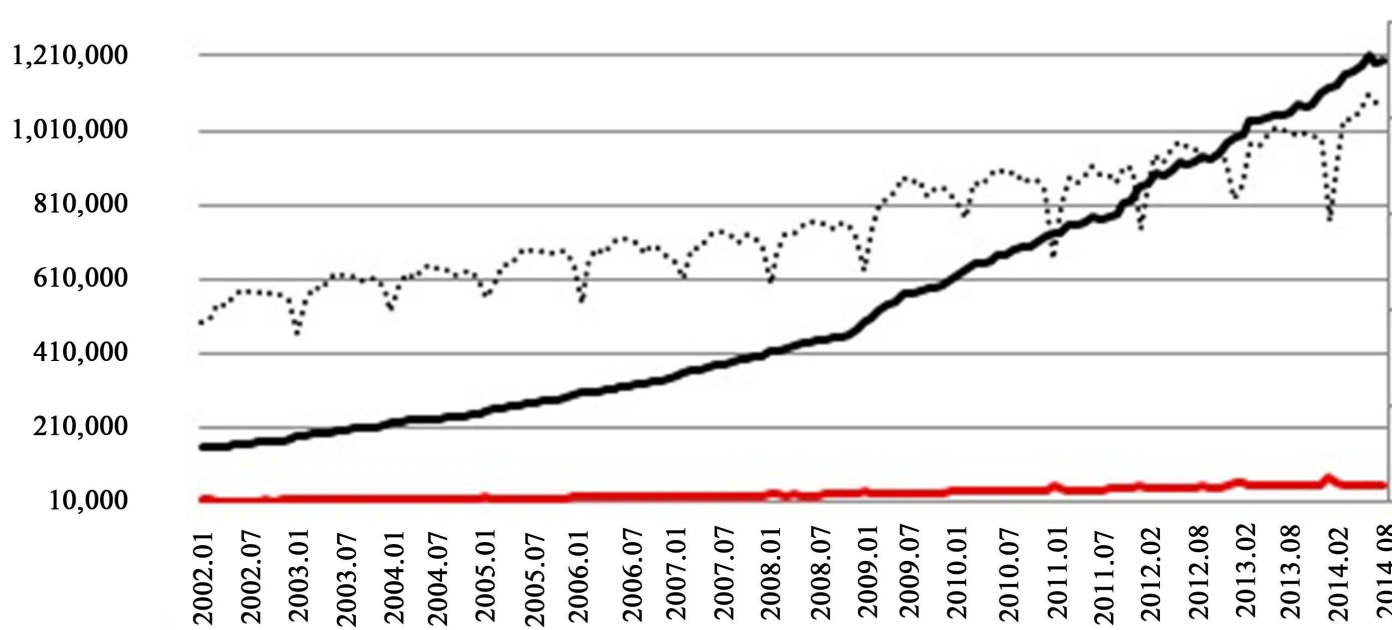


result, much of the money immediately flowed to the money market, and the value of Yuan returned to almost its original level. This is the biggest reason why money brimmed over in the market.

\subsection{Price Increase of Real Estate}

Table 1 shows the increase in land price for 14 years, 2000-2014: the price $/ \mathrm{m}^{2}$ of commercial site increased by 304.2\% from $1615 \mathrm{Yuan} / \mathrm{m}^{2}$ to $6527 \mathrm{Yuan} / \mathrm{m}^{2}$, industrial site increased $64.4 \%$ from $444 \mathrm{Yuan} / \mathrm{m}^{2}$ to $730 \mathrm{Yu}-$ an $/ \mathrm{m}^{2}$, residential site increased by $467.3 \%$ from $923 \mathrm{Yuan} / \mathrm{m}^{2}$ to $5236 \mathrm{Yuan} / \mathrm{m}^{2}$, and comprehensive site increased by $208.7 \%$ from $1129 \mathrm{Yuan} / \mathrm{m}^{2}$ to $3485 \mathrm{Yuan} / \mathrm{m}^{2}$ respectively. In this period, all kinds of land prices increased rapidly, and so did the housing prices.

Among the land prices, the type of land having the highest increase in value was residential land. This trend reflects unusual situations of demand for real estate during this period and that it led high growth rate of GDP for the period.

\subsection{Prior Studies on Chinese Bubble Economy}

Most experts in the field of Chinese economy believe that the Chinese economy has been facing the state of a so-called real estate bubble. In a "Bubble economy", the price of asset such as real estate and commodities rises by speculation beyond their original value (The same as "fundamental" price of asset) and there is an existence of excessive money in the money market.

Experts have given differing definitions of a bubble (Fabrizio Zampolli, 2006), (Gadi Barlevy, 2007), (Robert A. Jarrow, Philip Protter, \& Kazuhiro Shimbo, 2007), type B; (Kunio Okina, Masaaki Shirakawa, \& Shigenori Hiratsuka, 2001), (Karl E. Case \& Robert J. Shiller, 2003), (Philip Arestis \& Elias Karakitsos, 2004), (Takanobu Nakajima, Alice Nakamura, Emi Nakamura, \& Masao Nakamura, 2007), (Hans Lind, 2009), (Dreger Christian \& Zhang Yanqun, 2010).

In this paper, the definitions are presented as type A and type B. Type A states that a bubble is when the current price of assets moves away from fundamentals, while type B argues that a bubble has no relation with fundamentals. For example, Zampolli (2006) said that "a reason for holding an asset even if the price is above that suggested by fundamentals is that there is a chance that it will continue to rise, generating an expected capital gain that compensates the asset holder for the risk of a price collapse". In addition Barlevy (2007) defines "a bubble is a situation in which the price of the asset deviates from its fundamental value, be it because the price exceeds the fundamental value or falls short of it ". Another definition that falls in type A states "the asset price bubble is the asset's market price less the asset's fundamental price” (Robert A. Jarrow, Philip Protter, \& Kazuhiro Shimbo, 2007). On the other hand, type B is a rapid rise in asset prices, the overheating of economic activity, and a sizable increase in money supply and credit (Kunio Okina, Masaaki Shirakawa, \& Shigenori Hiratsuka, 2001). Another definition given (Karl E. Case \& Robert J. Shiller, 2003) says that a bubble is "a situation in which excessive public expectations for future price increases cause prices to be temporarily elevated". Christian and Yanqun (2010) gave a similar definition saying that "an asset price bubble is a price acceleration that cannot be explained in terms of the underlying fundamental economic variables".

The clearest case of a bubble economy was the Japanese incident which took place in the late 80s and early 90s. When we analyze that Japanese bubble scene closely, we can find out that financial bubble has proceeded

Table 1. Observational price of land.

\begin{tabular}{cccc}
\hline & & \multicolumn{2}{c}{ (Yuan/m² \%) } \\
\hline & 2000 & 2014 & Change \\
\hline Commercial site & 1615 & 6527 & 304.2 \\
Industrial site & 444 & 730 & 64.4 \\
Residential site & 923 & 5236 & 467.3 \\
Comprehensive use & 1129 & 3485 & 208.7 \\
\hline
\end{tabular}

Source: Ministry of Land and Resources. Note: Actual price is higher than this price. 
by real estate bubble. But after more enthusiastic times, the real estate and land market suddenly shrank. The bubble economy of Japan fully collapsed in the 90s. The reason of the burst of Japan's bubble economy was the rapid restrictive monetary policy by Japan Central Bank. In this aspect, it can be said that financial bubble and real estate bubble have strong correlation.

\section{The Players of the Bubble Economy in China}

The meaning of "players of bubble economy" is defined here as a person or a group who contributes to expanding the bubble economy and let the bubble economy to continue and those who earn profit from the bubble economy. The typical players are 1) the People’s Bank of China, 2) Real estate developer, 3) Local Government, and 4) Shadow banking.

\subsection{The People's Bank of China}

As shown in Figure 5, PBC has continued to issue a huge amount of base money for more than 20 years. When RMB had evaluated, PBC adopted the sterilization policy, namely they bought many kinds of bonds from the market or adopted reverse repo operations and repo operations to spread RMB in the real estate market. PBC spread 2.894 trillion Yuan (US \$470 billion, PBC, “Open Market Operations transaction announcement”) with reverse repo operations and repo operations in 2013. The monthly breakdown of the 2.894 trillion Yuan is shown in Figure 6. This figure shows that the Chinese repo operations were performed throughout the year and concentrated at the end of January and beginning of February (Takahashi, 2013).

\subsection{Real Estate Developer}

There are three roles of state developers emphasized in this paper. The first role of real estate developers is to buy land from the local government and develop it for housing site where houses and shopping streets and others are later constructed. Some developers sell the land with a higher price to other developers and get more high commercial benefit. The second role of developers is to become a borrower of huge operating funds from a bank. And the third role is to supply funds of high investment yield of WMP, Wealth-Management Products. An investment yield from Wealth-Management Products is higher than bank deposit interest rates, stock profits, bond yields, formal financial instruments, and corporate profitability.

Table 2 shows, among various investment ways, that the lowest interest rate is $0.35 \%$ per year for savings. Second to this is time deposit with the interest rate of $2.75 \%$ per year. The third one is stock average yield of Shanghai market which is $7.76 \%$ per year. The fourth one is company profit rate which is $8.10 \%$ per year. The highest rate is wealth investment product (Yi Long Huo company: one of those involved in shadow banking) which is $18.00 \%$ per year. The reason why investment yields from Wealth-Management Products is higher than those of other yields is because the developers can increase the price of properties freely after they developed them. Developers issue Wealth-Management Products in cooperation with banks or financial companies.

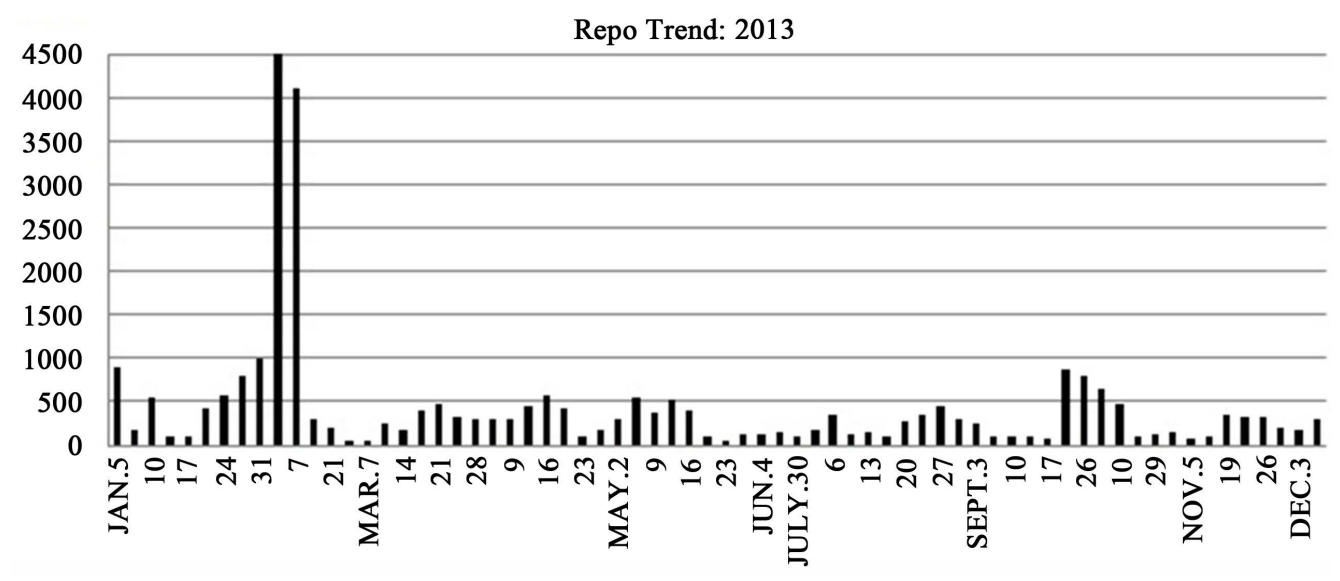

Figure 6. Repo Trend: 2013. Source: PBC. 
Table 2. Various financial instruments yield/year comparison: as of Nov. 2014.

\begin{tabular}{cc}
\hline & (\%) \\
\hline Savings interest rates & 0.35 \\
Time deposit interest rates/year & 2.75 \\
Shanghai stock average yield (2014, November27) & 7.76 \\
Major company profit rate & 8.10 \\
Wealth investment products (Yi long huo) & 18.00 \\
\hline
\end{tabular}

Source: Yi Long Huo (investment firm), China Statistical Yearbook, PCB.

\subsection{Local Government}

The roles of the local government are to expropriate farmland from farmers, giving them little compensation, under the "China Land Management Act", and afterwards sell them to developers with high sales gains. Through this transaction the farmland turns from a property having no value into gold. It is like "alchemy". In China, land price is composed of four categories, namely residential land price, commercial land price, industrial land price, and comprehensive land price. It should be noted however that farmland has no price legally. Therefore, the local government can take the land from farmers without paying them. When they sell the land to developers, it is not sold as farmland anymore. It changes to residential or commercial land or others with high price. Basically, the local government purchases the land for free, and then sells it to a trading partner at a high price. Through such course, developers can get land capital to make money for their business. It can be said that the local government plays as the agent of developers, because developers cannot buy the farmland from farmers directly.

\subsection{Shadow Banking}

The definition of the so-called shadow banking in China includes 1) Small non-banking groups, 2) Agencies for housing loan, 3) Local lending platforms, 4) Some of state-owned enterprises, 5) Some black billionaires, 6) Normal banking feigning as non-banking, and 7) Developers (see Table 3). According to "China monetary policy report” (Chinese Academy of Social Sciences Institute for Monetary Studies, May 11, 2014), the amount of loan transacted through shadow banking was 40\% of GDP in 2013. It means that China has 22 Trillion 753.8 Billion Yuan (US \$3612 Billion) of shadow banking loan (IMF estimated 25\% of GDP, 14trillion Yuan in May 2014 (Global Financial Stabilit Y Report: Risk Taking, Liquidit Y, and Shadow Banking-Curbing Excess While Promoting Growth, Oct. 2014).

The substance of the shadow banking mentioned above is as follows:

Player 1) Small non-banking: for instance, pawn shops lending to individuals for down payment for housing loan and small consumer loans. They are real estate bubble players and financial bubble players.

Player 2) Agencies for housing loan: small private agencies looking for non-qualified personnel of mortgage borrowing some lenders-. They are real estate bubble players.

Player 3) Local government's lending platform (Sun, 2013): one of the organizations in the local government which demands investment of high-interest rate from surplus funds from the money market. Those who are under this are financial bubble players.

Player 4) Some of state-owned real estate enterprises: the enterprises which demand investment of high-interest rate from surplus funds in the money market. They are financial bubble players.

Player 5) Some black billionaires (Identity is unknown for super-rich people): the unidentified rich people who seek a high-interest rate investment. They are financial bubble players.

Player 6) Normal banking feigning as non-banking: they use investment as financial instruments or WealthManagement Products. They are also financial bubble player s.

Player 7) Real estate developers: sell Wealth-Management Products in cooperation with banks to have development funds, and pay the principal and interest after selling the developed asset with high price. 
Table 3. Structure of shadow banking.

Small non-banking
Agency for housing loan
Local lending platform
Some of state-owned enterprise
Black some billionaire
Normal banking which feign as non-banking
Developer

\section{Emerging Structure of Bubble Economy}

The structure those players play in the making of the Chinese bubble economy is so complicated as shown in Figure 7. This figure shows that the fundamental reason of the Chinese bubble economy comes from the expropriation of farmland by local government and the excessive money in the financial market (Guo, 2001). These two factors are the base of the bubble economy, while expropriation is the base of real estate bubble and excessive money is the base of financial bubble. These two factors become starting points, and then other factors or players related to them begin to move them toward the bubble economy as they remain mutually interrelated. Factors and players have a mutual relationship and affect other players directly and indirectly. In this figure, mark 1) shows the first step of the two basic factors and their important role in the transactions. Marks 2) - 7) show the next steps following the first step. Based on this figure, the two pathways to the bubble economy are illustrated, while the relationship between the main players is explained. One of the pathways is toward real estate bubble (pathway A); the other is toward financial bubble (pathway B).

Pathway A: 1) The local government expropriates farmland from farmers. 2) The local government sells the land to developers. 3) The local government takes huge money. 4) The local government invests huge amounts of money to their institution, namely local government financing platform. 5) The local government financing platform invests in some local business operations and 6) shadow banking. 7) The land and housing markets expand and steps 1) $\Rightarrow 2$ 2) $\Rightarrow 3$ ) are repeated. The developer develops the land and builds houses, and house buyers borrow money from banks to pay. Some buyers borrow money from non-banking institutions. 4) The developer sells the houses to buyers. 5) The developer invests in irregular financial market (shadow banking field).

Pathway B: 1) Massive amount of money is issued by PBC to the financial market, and money from abroad comes in to shadow banking field as inward investment. 2) The massive amount of money transfers to regular financial market. 3) Regular financial market invests in irregular financial market. 4) Irregular financial market invests in developer and home sakes market. 5) Irregular financial market gains high yield result. 6) Through repeating such transactions, the market scale of shadow banking field expands.

\section{A Case Study-Housing Bubble Seen in Beijing, Harbin, and Xinxiang}

\subsection{Increased Burden of Housing Loans}

The price of a house in Beijing has been increasing for two decades. The lowest price of a house in Beijing was 7000 Yuan ( $\$ 1150 \mathrm{US}) / \mathrm{m}^{2}$ in November 2014, and the average price of a house was 35,000 Yuan (US $\left.\$ 5800\right) / \mathrm{m}^{2}$. Most house buyers borrow money. The conditions for a housing bank loan are; down payment is $30 \%$ of the price of the house, average loan period is 20 years, interest rate is $6.15 \% / y e a r$, and the average area of the house ranges from $90-150 \mathrm{~m}^{2}$.

Table 4 shows prices and total payments for a house with the smallest area and with an average area. The lowest priced house has an area of $146 \mathrm{~m}^{2}$ and costs 1,022,000 Yuan. An average house with an area of $154 \mathrm{~m}^{2}$ costs 5,390,000 Yuan. For the first case, the total payment to be paid to the bank is 1,244,987 Yuan, while 6,566,030 Yuan for an average one. As for the total payment for the first and the latter, the principal is 715,400 Yuan and 3,773,000 Yuan respectively, and interest paid is 529,587 Yuan and 2,793,030 Yuan respectively.

The most important for a borrower to consider is the scale of the monthly payment. It is 5187 Yuan in the case of buying the lowest priced house and 27,358 Yuan in the case of buying the average one. The monthly av- 


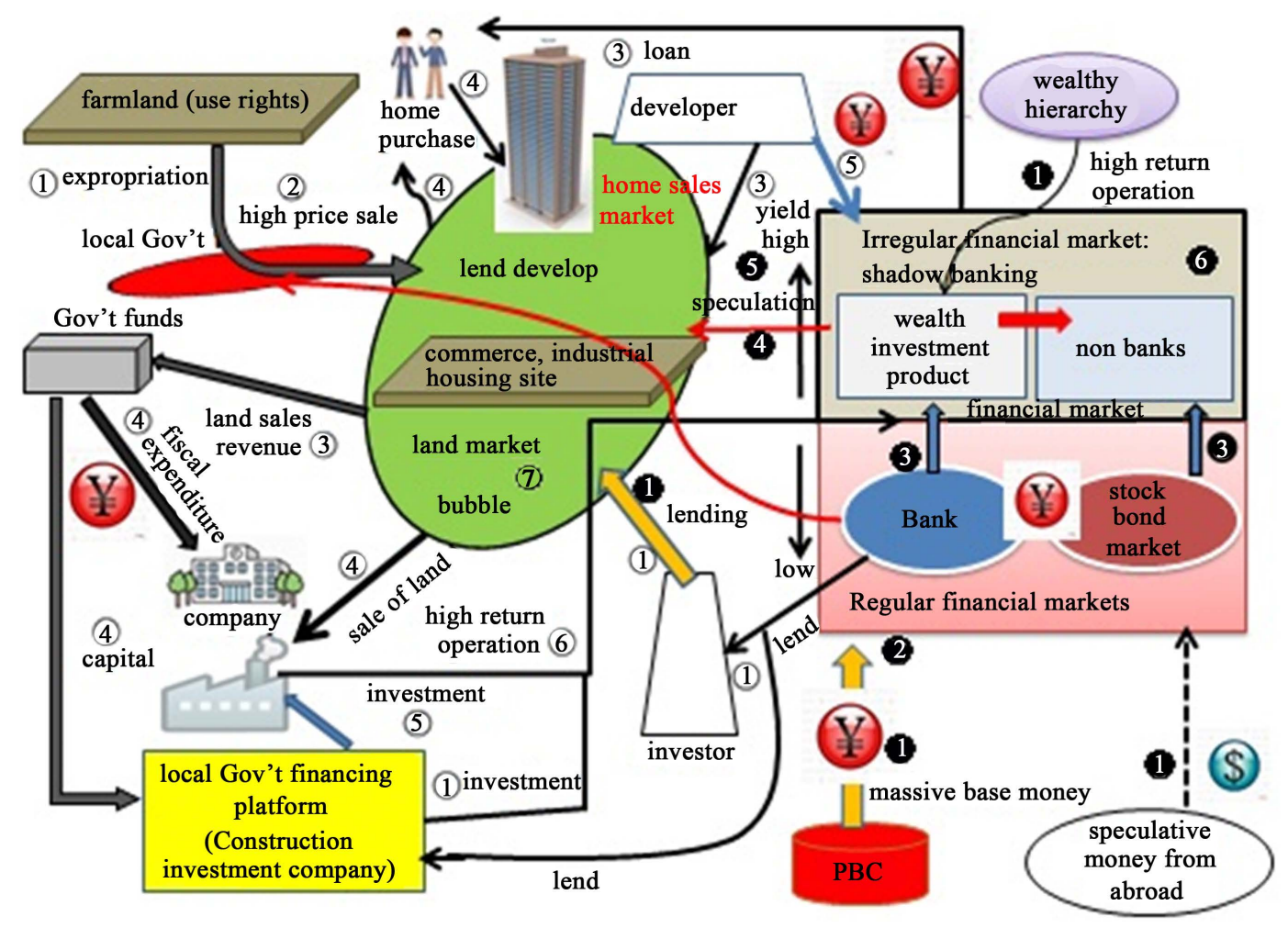

Figure 7. Structure of Chinese bubble economy: The role of players.

Table 4. Current state of the mortgage: Beijing 2014.

\begin{tabular}{cccccccc}
\hline & $\begin{array}{c}\text { Unit price } \\
\text { (Yuan) }\end{array}$ & Area & Price & $\begin{array}{c}\text { Down } \\
\text { payment }\end{array}$ & $\begin{array}{c}\text { Loan } \\
\text { period }\end{array}$ & $\begin{array}{c}\text { Interest } \\
\text { rate }\end{array}$ & $\begin{array}{c}\text { Borrowing } \\
\text { principal }\end{array}$ \\
\hline Lowest price & $7000 / \mathrm{m}^{2}$ & $146 \mathrm{~m}^{2}$ & $1,022,000$ & $30 \%$ & 20 years & $6.15 \%$ & 715,400 \\
Average price & $35,000 / \mathrm{m}^{2}$ & $154 \mathrm{~m}^{2}$ & $5,390,000$ & $30 \%$ & 20 years & $6.15 \%$ & $3,773,000$ \\
\hline & $\begin{array}{c}\text { Total } \\
\text { borrowing }\end{array}$ & $\begin{array}{c}\text { Interest } \\
\text { paid }\end{array}$ & $\begin{array}{c}\text { Monthly } \\
\text { repayments }\end{array}$ & $\begin{array}{c}\text { Average } \\
\text { wages/year }\end{array}$ & $\begin{array}{c}\text { Magnification of the price } \\
\text { for wages }\end{array}$ & $\begin{array}{c}\text { Distance to } \\
\text { heart of city }\end{array}$ \\
\hline Lowest price & $1,244,987$ & 529,587 & 5187 & 69516 & 14.7 times & $133 \mathrm{~km}$ \\
Average price & $6,566,030$ & $2,793,030$ & 27,358 & 69516 & 77.5 times & $20 \mathrm{~km}$ \\
\hline
\end{tabular}

Data: http://newhouse.fang.com/(Vov.10.2014), and by Takahashi.

erage wages of Beijing citizen is 5793Yuan (in 2013: Beijing Bureau of Statistics 2014). So the magnification of the price in relation to the wages is 14.7 times for the lowest one and 77.5 times for the average one. If a couple both breadwinners buy the lowest one, it might be possible for them to pay and live in the area where the low cost housing site is. But then again, the distance to the heart of city is an average of $133 \mathrm{~km}$ if the couple works in the city. It might be impossible for them to work in the working area of Beijing if they live $133 \mathrm{~km}$ away. Moreover, they might not be able to look for a good job in the suburb of Beijing area. With little or no choice, most house buyers accept to be a "house loan slave". Many of them can certainly not afford to buy an averagepriced house on the inside of the sixth ring road, a relatively convenient location for commuting.

\subsection{Field Work of the Market}

I visited three cities in China in June and August 2014 to carry out field research to observe the selling situation in the area of several hundreds of huge buildings of collective housing. The places were Beijing, Harbin, and 
Xinxiang (Henan province). One very gorgeous collective housing costs 700 million Yuan/one house and 3.5 million Yuan $/ \mathrm{m}^{2}$. A real estate agent salesperson said that most of the houses were already sold out, because the location of the houses is in the heart of Beijing and that they have wealthy customers. I went to another area of collective housing in a suburban of Beijing; the area of the site is 164 acre. The total number of buildings of collective housing is 30 , and the biggest building has 50 floors. The total population if all units are occupied is about more than 60,000. However very few visitors were there. Another site is located at one hour distance to the center of Beijing by bus and is along the highway. The price of a house is $12,000 \mathrm{Yuan} / \mathrm{m}^{2}$. The price is only $30 \%$ of the average price of houses in Beijing. But most of the collective houses are unsold, despite the fact that the down payment is lower and that the bank lowered interest rates for customers by $6.0 \%$. The reason for this and the very few visitors to the housing site is because most Beijing citizens know they will definitely become loan slave if they buy a house at that site. One saleslady admitted that the price of the houses is unusually expensive for common citizens. When asked of the price level that people can afford per one $\mathrm{m}^{2}$, she answered that the appropriate price level is $5000-7000 \mathrm{Yuan} / \mathrm{m}^{2}$. If this is true, the number of unsold houses will increase because developers in that area have kept on buying expropriated land and building a lot of houses.

\subsection{The Past Real Estate Policies of China}

The real estate policy of the Chinese government has changed several times as shown in Table 5 . The policy has changed according to the situation of real estate market. Right after the Lehman Shock, the market shrank, and the government adopted financial expenditure policy as a countermeasure. The policy involving housing market in 2008 reflected the situation. After 2008, the market expanded. And then the policy had been tightened by 2013. The Chinese government was afraid of bursting the bubble and changed the housing policy in the autumn of 2013. The situation changed almost suddenly in spring of 2014 after this change in policy, the reflection of increasing of unsold houses, and the thrift ordinance by President Xi Jinping. The market has begun to cool.

The market situation at present is cooling down, but a heavy heating policy may be put in place again. On the other hand, the management crisis of developers has come to a dangerous stage. The central government cannot stand to inhibit the heating situation of the market, and they may want to convert the housing policy into another policy in order to rescue developers, banks, non-banking institutions, some local governments, and other players of the bubble economy. Such policies done to prevent collapse, in turn, have entered in a vicious circle to cause more serious collapse. After all, there is only one possibility of a remaining policy for the Chinese government, the price freeze policy.

Figure 8 shows price changes of houses in Beijing from Dec. 2013 to Nov. 2014. The price started increasing by May. 2014 and kept increasing, and then it began to decrease in June. The trend has been continuing up to Nov. 2014. In the beginning of every month, commentators of real estate industry have predicted several times that "the price of houses in Beijing will definitely begin to increase from the next month". They have been repeating the same prediction, but there has been to significant increase in house prices so far.

There are three groups in which the average price $/ \mathrm{m}^{2}$ of a house in Beijing is divided in Nov. 2014 (see Figure 9). The first group is less than $10,000 \mathrm{Yuan} / \mathrm{m}^{2}$. The second is $20,000-30,000 \mathrm{Yuan} / \mathrm{m}^{2}$, and the third is 40,000 Yuan or more $/ \mathrm{m}^{2}$. The third group, 40,000 Yuan or more $/ \mathrm{m}^{2}$, should be divided to $60,000-70,000 \mathrm{Yuan} / \mathrm{m}^{2}$,

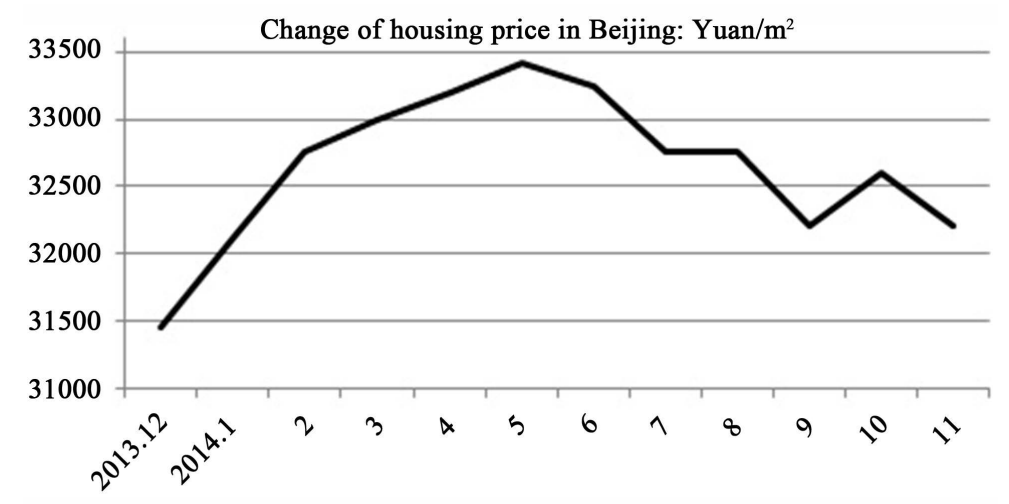

Figure 8. Source: http://newhouse.fang.com/ (Nov. 13, 2014). 


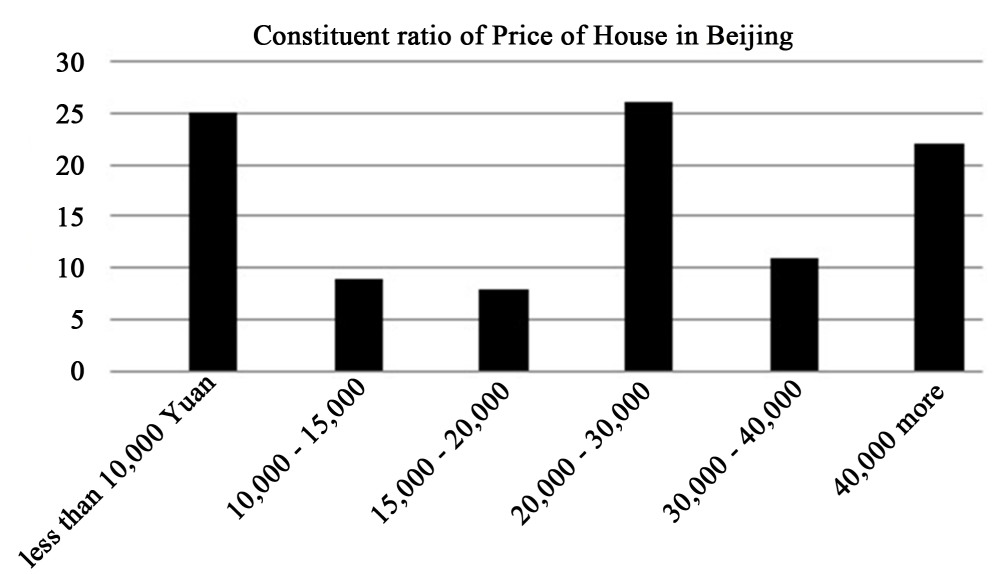

Figure 9. Constituent ratio of price of Home in Beijing. Source: http://newhouse.fang.com/ (Nov. 13, 2014).

Table 5. Changing of housing policy.

Oct. $2008 \quad$ Change of policy

Back ground

Effect of the policy change

Sept. 2009

Change of Policy

Back ground

Effect of the policy change

Mar. $2010 \quad$ Change of Policy

Back ground

Effect of the policy change

Sept. 2011 Change of Policy

Back ground

Effect of the policy change

Sept. 2012

Change of Policy

Back ground

Effect of the policy change

Sept. 2013

Change of Policy

Back ground

Effect of the policy change

sept. $2014 \quad$ Change of Policy

Back ground

Effect of the policy change
Reduction of loan interest rate and decrease to $20 \%$ of $\%$ of down payment.

$19.7 \%$ down of housing area and $20.1 \%$ down of housing sales in 2008.

Huge amount of money in flowed to real estate market and price of house increased.

Increased $\%$ of down payment to $30 \%$. When buy second house, the $\%$ is $50 \%$.

Rising of loan interest rate to 1.1 times to basic interest rate.

Increase of interest rate and \% of down payment for buy third or more houses by bank loan.

Price of house soared to highest level so far.

Price of house soared like before.

Increased to $40 \%$ of $\%$ of down payment when buy second house.

Price of house in 70 cities soared $11.7 \%$ to previous year in Mar. 2010

Price of house still increased but the trend lowered.

Raising the deposit reserve ratio of banks and raising basic interest rate.

Number of city of sales restrictions for house increased by 50 cities.

Increased to $60 \%$ of $\%$ of down payment when buy second house.

Rising of loan interest rate to 1.1 times to basic interest rate.

Overheating of the market.

Still price of house increased and market of real estate expand. Business of developer expand.

Keep to $60 \%$ of $\%$ of down payment when buy second house.

Decreased basic interest rate and stimulate housing market.

Sales area of house is .113 billion square meters, increaed by $1.8 \%$ to previous year. Price of first class city of house decreased $1 \%$.

Rising of \% of down payment for second house and loan interest rate.

The sales tax of own house set $20 \%$.

Increased to $70 \%$ of $\%$ of down payment when buy second house.

Overheating of the market.

The real estate market is calm, but construction of house, sales amount,

Un-sold house and house transaction increased.

40 cities canceled restriction policy.

Central bank adopt relaxation policy for housing market.

Cooling of housing market.

Price of house in decreasing and vacant houses is increasing.

Source: Chinese people’s daily, Oct. 10, 2014. 
$70,000-100,000 \mathrm{Yuan} / \mathrm{m}^{2}$ and 100,000 Yuan or more $/ \mathrm{m}^{2}$. There is a lower limit for the price of a house in order for developers and real estate dealers to maintain management, but there is no upper limit for the price in Beijing. As the total payments including interest is about 4800 thousand Yuan when purchasing a house with an area of $100 \mathrm{~m}^{2}$, the conditions are $30 \%$ of down payment, $6.55 \%$ /year of interest rate , 20 years of loan period, and a monthly payment of 20000 Yuan. Those who are be able to pay 20,000 Yuan a month must be the wealthy few. The biggest problem is that the number of wealthy people is not really that many, and thus many unsold houses are referred to as "ghost houses".

\section{The Risk of the Bubble Markets}

\subsection{Unsold Houses}

Under the trend of investment by developers and the local governments, the number of unsold houses as a whole does not stop the development of the country. Figure 10 shows the detailed situation of the trend, namely the number of units of cumulative unsold houses in China is rapidly increasing. The number of units of cumulative unsold houses had reached 11 million 473 thousand in 2013. Southwest University of Finance and Economics in Sichuan province has estimated more than 50 million new houses in China are unsold.

When the so-called Lehman Shock happened, the Chinese central government spent 4 trillion Yuan of financial expenditure. That stimulated the building of many units of expensive houses over the demand of the housing market. Consequently, unsold houses appeared. Also, speculative funds have flowed to the housing market, and the price of houses began to soar.

\subsection{Real Estate Developers}

The number of state-owned developers is 4775 in 2004, but it decreased to 3353 in 2012, and 1739 in 2013. The degree of reduction per year is biggest between 2012 and 2013, which is 50\% (NBSC). The main reason of the reduction is bankruptcy. One medium-sized real estate developer was bankrupted in December 2014 by its parent company, a state-owned and one of the largest developers in China. The bankrupted developer was established in Beijing in 2006 with a capital of 100 million Yuan (about US \$16 milion). By September 2014, the total assets were 14 million Yuan and the total liability was nine million. Nevertheless, there was no business revenue in 2014. Neither was there any business revenue for the past three years. The net profit was a deficit of 13 million in 2011and 460 thousand in 2012. The parent real estate developer was established in 1993 at Chongqing with a capital of 300 million and the company has 4 wholly owned subsidiaries, 5 holding companies and a shareholding enterprise, business development to include areas of real estate development, industrial real estate management, and property management. The companies in Beijing, Shanghai, Shenzhen, Changsha, Xi'an, Tianjin and other cities have developed a number of residential, office and industrial real estate projects. But the business situation of the parent real estate developer has worsened in recent years. In 2014, the business revenue for three months (July to September) was only 49 million Yuan, year-on-year minus 50\%, and attributable to shareholders net profit was only 12 million Yuan minus 165\% for previous year. The financial statements of the

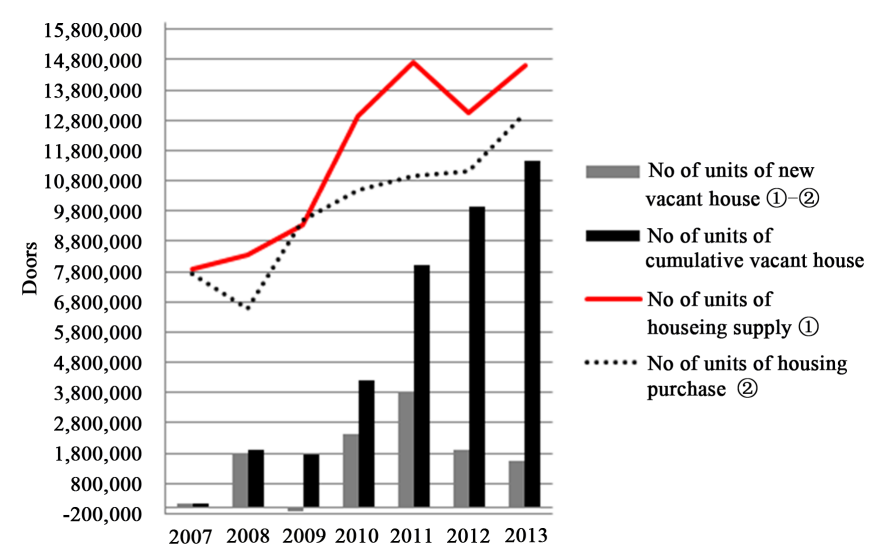

Figure 10. No. of unsold houses. Source: NBSC et al. 
developer were analyzed, and it was found that the fundamental problem of the current business situation came from increasing unsold real estates, worth 49 billion in September 2014, which increased 54\% during the same period of the previous year. In addition, the long-term debt increased $100 \%$ for the same period to 867 million Yuan (Financial statements of third period 2014). The foregoing description means that the parent company made the subsidiary go bankrupt because the management of the parent company's real estate business has deteriorated and because the subsidiary's financial situation has also worsened.

Some of studies (Sun, 2010) reported that the problems on real estate developers in China have occurred from management failure. In summary, the problems presented in these studies are as follows: 1) Lack of management experience, 2) Management funding difficulties, 3) Excessive number of labor personnel, 4) Sloppy operation of personnel system, 5) Pre-modern management style, 6) Lack of competitiveness, 7) Lack of farmland to develop, and 8) Too many unsold houses.

The business situation of real estate developers is not good. The number of state-owned real estate developers will inevitably be reduced as long as they cannot reform their styles of management and their work culture. Some real estate developers have those problems, and those problems will be the reason for their business failures. If many real estate developers go bankrupt, there is a high possibility that that situation will trigger the collapse of the bubble.

\subsection{Normal Banking}

Normal commercial banks also act as fund operators of excess funds in the money market, which poses high risk. Their typical way of doing this is by issuing many kinds of Wealth-Management Products. Deposit interest rates are regulated, so normal banks cannot collect money from a wide range of investors who have excessive money. Normal commercial banks also follow a regulation on loans: the ratio of loan to deposit is $75 \%$. It means normal commercial banks cannot lend money beyond $75 \%$ of the amount of deposits. And at least $25 \%$ of the deposits have to be invested using ways of fund management other than lending; the method is investing money in some Wealth-Management Products or some of bonds etc. Another way for normal banking groups to invest their excess money is by owning subsidiaries. This is when a commercial bank feigns to be a non-banking institution. At this time normal commercial bank changes to one of non-banking businesses and may at times enter into the world of black market.

In China, the loan to deposit ratio of Chinese normal commercial banks was 68.8\% in April 2012. During that time, the banks had 26 trillion 298 billion Yuan (US \$4 trillion 174 billion) excess money. That amount of money was equivalent to 51\% of the GDP in 2012. Therefore, 26 trillion 298 billion Yuan was invested in nonbanking business field or bonds etc. According to "China monetary policy report", the amount of loans from shadow banking was more than $40 \%$ of the GDP (China monetary policy report) in 2013. That means China had 22 trillion 754 billion Yuan (US \$3612 Billion) of shadow banking loan. So we can estimate the shadow banking's loan through normal banks, which is almost equivalent to $40 \%-50 \%$ of China's recent GDP. It can be said that normal commercial banks at times feign as non-banking institutions through these abovementioned methods.

\subsection{Small Non-Banking Institutions}

The number of Chinese small non-banking is 8127 in 2014 (PCB: financial data 2014), designated as a supervisory subject by the PCB in April 2013 (Small loan companies and financing guarantee company access to financial credit information database management law). But since the number of small non-banking institutions is too many and they have spread nationwide, the supervision of PCB does not work well. Outstanding loans of small non-banking were estimated to be 844 billion Yuan in 2014 (PCB: financial data 2014). The scale of loan by non-banking is very small compared with that of normal commercial banks. The management skills and financial power of the sector is very low. As Figure 11 shows, since the financing ability is low, lending funds can do nothing but borrowing at high interest rate from a normal commercial bank. In this regard, normal commercial banks and small non-banking will have the contacts. Then both sectors will later be active in the same business environment.

The scale of non-banking and real estate developers is commonly a small scale business. Moreover, their business market is also small, namely their revenue comes from low-income buyers of real estate assets. So, the fate of their business fate is held by low-income buyers of real estates. For 10 years, the low-income buyers oc- 


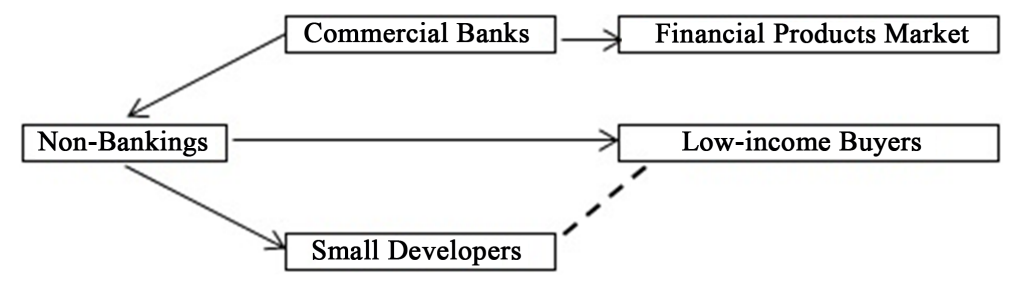

Figure 11. Money flow in real estate sector.

cupy about 20\% (China Business Intelligence Network, http://www.askci.com/news/201312/25/2516554235078.shtml (Nov. 25, 2013)) of new home buyers who borrow money from non-banking institutions including public financial reserve. The average period of a loan is 20 years. Their loan started sometime in 2003-2004, and thereafter the Chinese GDP had been increasing to more than $10 \%$ per year. Their income level also increased every year. But the growth rate is going down nowadays; the income level of low-income citizens will surely experience a sluggish growth.

\section{The Risk of the Financial Policy}

As mentioned above, the internal factors intertwined in the Chinese economy that can trigger the collapse of the bubble are not few. The economy of all countries will collapse easily if they have the same conditions that China faces. China's case is different however. It has a built-in distinctive safety system in its economic structure. Firstly, the Chinese authority can operate economic mechanism by strong power. Secondly, the Chinese authority can conceal events that happen with regard to its economy. The possible collapse of the bubble economy in China is very high, and if it happens it will be concealed by the Chinese authority.

Nevertheless, if a chain reaction of bankruptcy among real estate developers and shadow banking happens, the control of collapse will be difficult to conceal. PCB has been issuing tremendous amount of RMB into the financial market for this two decades. The purpose of the monetary policy of PCB is to prevent in advance the collapse of the bubble economy. This money policy worked well and was to facilitate the circulation of money in the market.

The most common way to conceal the collapse will be the resetting of the maturity dates of liabilities. Table 6 shows that after 2004, bad loans started to decrease. On the contrary, the ratio of long-term loans started to increase. This means that most of the banks replaced some of the short-term loans to long-term loans. If the banks replace short-term loans to long-term loans, they inhibit past due loans or loans like that. By repeating this operation, most of the bad loans may be taken as normal loans.

Nevertheless, we cannot abandon the idea that a risk of bubble collapse exists. If the Chinese financial authority makes a mistake in controlling the financial market, the possibility greatly increases. PCB deregulated the lending rate, but the deposit rate is still regulated. Figure 12 shows the flow of the mechanism of money in the financial market. As the official rate is low (mark R1), many investors aspire to invest their money in shadow banking or high rate (mark R2) of Wealth-Management Products and not to banking deposits. The reason why the volume of shadow banking has increased further comes from this interest rate system. This consequently results in many parts of funds going to the field of shadow banking business (mark graphic of triangle).

The problem will occur when official deposit interest rate is deregulated in the near future. When the rate (R1) goes up by R1', the part of investment in shadow banking (mark I) should transfer to bank deposit field. If that happens, shadow banking will face collapse. So we can say that the trigger of collapse comes from the regulation of interest rate policy. The president of PCB, Mr. Zhou Xiaochuan, has announced that PCB will deregulate the deposit interest rate within two years. If PCB deregulated not only the lending interest rate but also the deposit rate simultaneously in July 2014, a concern like this would not appear. This is the big mistake made by PCB.

\section{Conclusion}

This paper insists that we need to understand that the aspects of the Chinese bubble economy have an entirely different status, namely latent status and obvious status. In the latent status, Chinese government intervenes in the status, it will not collapse obviously.

But if some conditions occur, latent status will convert to obvious status and the bubble economy will collapse obviously. One of the conditions of the collapse is the accumulation of unsold houses. Many developers 
Influence of regulation of Deposit interest rate

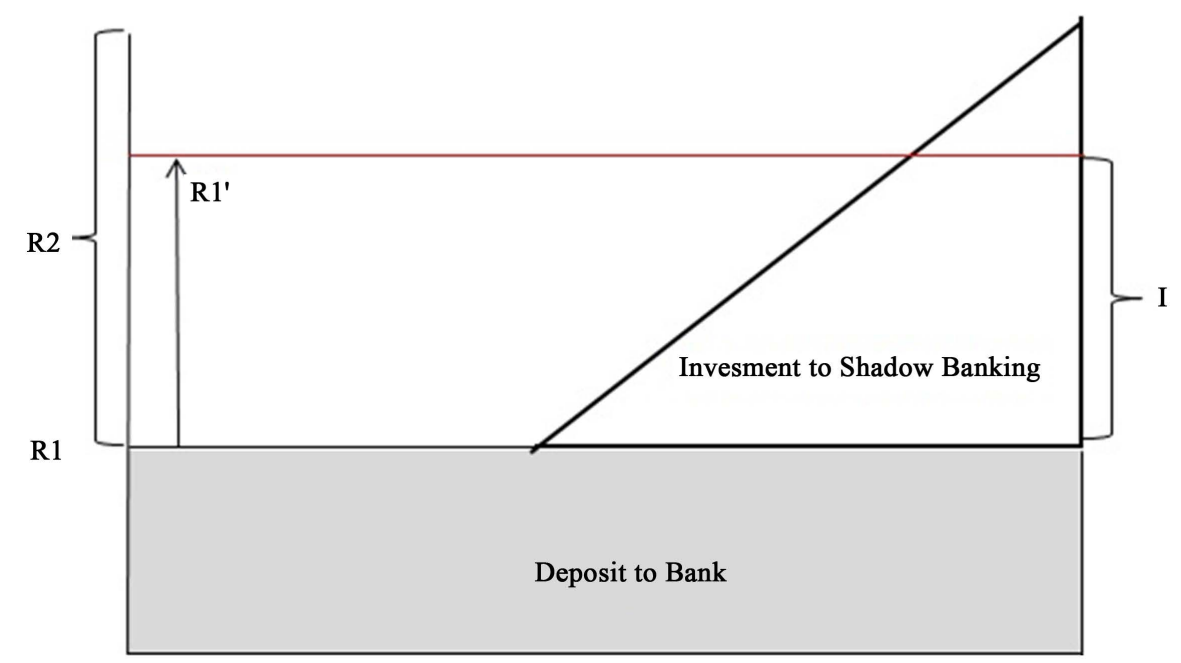

Figure 12. Influence of regulation of deposit interestrate. Rt: Deposit interest rate of Bank (regulation); R2: Return on investment; R1': Deposit interest rate of Bank (after deregulation); I: Amount of money of back to Bank.

Table 6. Mechanism to conceal bad debts.

\begin{tabular}{|c|c|c|c|c|c|c|}
\hline & \multicolumn{6}{|c|}{ (Unit: one hundred million yuan) } \\
\hline & Short-term loan & Long-term loans & Total loans & Percent defective & Bad loans & Long-term ratic \\
\hline 2000 & 65,456 & 24,605 & 90,061 & 22.4 & 20,174 & 27.3 \\
\hline 2001 & 63,816 & 34,313 & 98,129 & 29.8 & 29,242 & 35.0 \\
\hline 2002 & 68,501 & 41,424 & 109,925 & 26.0 & 28,581 & 37.7 \\
\hline 2003 & 77,717 & 52,032 & 129,749 & 20.4 & 26,469 & 40.1 \\
\hline 2004 & 87,245 & 67,375 & 154,620 & 13.2 & 20,410 & 43.6 \\
\hline 2005 & 89,437 & 80,084 & 169,521 & 8.6 & 14,579 & 47.2 \\
\hline 2006 & 91,773 & 925,24 & 184,297 & 7.1 & 13,085 & 50.2 \\
\hline 2007 & 105,135 & 113,404 & 218,539 & 6.2 & 13,549 & 51.9 \\
\hline 2008 & 120,086 & 140,104 & 260,190 & 2.4 & 6245 & 53.8 \\
\hline 2009 & 137,150 & 174,056 & 311,206 & 1.6 & 4979 & 55.9 \\
\hline 2010 & 149,346 & 251,516 & 400,862 & 1.1 & 4409 & 62.7 \\
\hline 2011 & 174,954 & 302,720 & 477,674 & 1.0 & 4777 & 63.4 \\
\hline \multirow[t]{3}{*}{2012} & 215,703 & 332,492 & 548,195 & 0.9 & 4934 & 60.7 \\
\hline & & & \multicolumn{4}{|c|}{ Bad debts hidden by period extension } \\
\hline & & & & \multicolumn{3}{|c|}{ (Prolonged short-term loans) } \\
\hline
\end{tabular}

Suorce: PCB.

are facing financing problems. If the number of bankrupt developers increases, the bubble will collapse. One more important consideration is the deregulation of the deposit interest rate by PCB.

Therefore, the most important thing is what authorities involved must strengthen the management ability to 
developers who has larger number of unsold houses, in addition, to control or shrink normal non-banking business and Wealth-Management Products, and the policy measure used to mitigate the deposit interest rate policy and its impact.

\section{References}

Arestis, P., \& Karakitsos, E. (2004). On the US Post—-New Economy” Bubble: Should Asset Prices be Controlled? CEPP Working Paper No. 01/04, Cambridge: Department of Land Economy, University of Cambridge, Centre for Economic and Public Policy.

Barlevy, G. (2007). Economic Theory and Asset Bubbles. Economic Aspects.

Case, K. E., \& Shiller, R. J. (2003). Prepared for the Brookings Panel on Economic Activity.

Dreger, C., \& Zhang, Y. G. (2010). Is There a Bubble in the Chinese Housing Market? Discussion Papers, German Institute for Economic Research, No. 1081. http://hdl.handle.net/10419/49455

Guo, X. L. (2001) Land Expropriation and Rural Conflicts in China. The China Quarterly, 166, 422-439.

Hiratsuka, S., Okina, K., \& Shirakawa, M. (2001). Monetary and Economic Studies. Institute for Monetary and Economic Studies, Bank of Japan.

Hoon, O. D., \& Ning, C. (2012). Case Studies of the Effects of Speculation on Real Estate Price Bubble Forming: Beijing and Shanghai (2001-2010). Eighteenth Annual Pacific-Rim Estate Society Conference.

Jarrow, R. A., Protter, P., \& Shimbo, K. (2007). Asset Price Bubbles in Complete Markets. Advances in Mathematical Finance, Applied and Numerical Harmonic Analysis, 2007, 97-121. http://dx.doi.org/10.1007/978-0-8176-4545-8_7

Jericho, G. (2014). China’s Housing Market Is on the Brink of Collapse. Should Australia Be Worried? The Guardian. http://www.theguardian.com/profile/greg-jericho

Lind, H. (2009). Price Bubbles in Housing Markets: Concept, Theory and Indicators. International Journal of Housing Markets and Analysis, 2, 78-90. http://dx.doi.org/10.1108/17538270910939574

Lu, Y. Q., \& Sun, T. (2013). Local Government Financing Platforms in China: A Fortune or Misfortune? IMF Working Paper.

Nakajima, T., Nakamura, A., Nakamura, E., \& Nakamura, M. (2007). Technical Change in a Bubble Economy: Japanese Manufacturing Firms in the 1990s. Empirica, 34, 247-271. http://dx.doi.org/10.1007/s10663-007-9040-5

Ranasinghe, D. (2014). China Real Estate: A Bubble Bursting? CNBC. http://www.cnbc.com/id/101945949\#

Sun, Z. L. (2010). Reform and Development of State-Owned Real Estate Developer. Guide of Sci-Tech Management, No. 24.

Takahashi, G. (2013). Excessive Base Money and Global Financial Crisis in Relation to the Essence of the So-Called "Abenomics”. Journal of Financial Risk Management, 2, 77-83. http://www.scirp.org/journal/jfrm

Zampolli, F. (2006). Optimal Monetary Policy in a Regime-Switching Economy: The Response to Abrupt Shifts in Exchange Rate Dynamics. Journal of Economic Dynamics and Control, 30, 1527-1567. 